Pak. j. sci. ind. res. Ser. A: phys. sci. 2019 62A(3) 190-196

\title{
Outdoor Air Quality as Influenced by Vehicular Exhaust in Metropolitan City of Lahore, Pakistan
}

\author{
Saif-ur-Rehman Kashif*, Sadia Ismail Shah and Fariha Arooj \\ Department of Environmental Sciences, University of Veterinary and Animal Sciences, Lahore, Pakistan
}

(received May 28, 2017; revised April 6, 2018; accepted September 7, 2018)

\begin{abstract}
This study was conducted to estimate the contribution of vehicular exhaust gases towards ambient air quality in Lahore, Pakistan during 2017. LANDCOM-III flue gas analyzer was used for determination of vehicular exhaust pollutants $\left(\mathrm{CO}, \mathrm{SO}_{2}, \mathrm{NO}_{2}, \mathrm{NO}, \mathrm{H}_{2} \mathrm{~S}, \mathrm{HC}\right)$ for five vehicles groups (motor bikes, Qingqi rickshaw, local cars, imported cars and public transport vans) from April to September, 2017. Major pollutants were compared with their National Environmental Quality Standards (NEQS) for the country. Ambient air quality was monitored using Haz scanner HIM-6000 during smog formation in the city in October and November, 2017. From the study, it was concluded that except local and imported cars, all vehicles groups emit high concentration of pollutants as compared to the standard values. It is also observed that public transport vehicles i.e. Qingqi rickshaw and vans contribute more towards atmospheric pollution as compared to other vehicle groups in the city. During smog formation in the city, $\mathrm{PM}_{2.5}$ and $\mathrm{PM}_{10}, \mathrm{NO}, \mathrm{NO}_{2}\left(\mathrm{NO}_{\mathrm{x}}\right)$ concentration was decreased whereas concentration of $\mathrm{O}_{3}, \mathrm{H}_{2} \mathrm{~S}$ and VOCs increased in November than October. Ozone concentration during the smog was below NEQS indicating that smog was not totally photochemical smog but mainly originated from vehicular and industrial exhaust gases.
\end{abstract}

Keywords: ambient air quality, smog formation, vehicular exhaust

\section{Introduction}

Lahore which is the second largest city of Pakistan has a total population of 11.2 million heads, thickly populated on an urban area of about $1700 \mathrm{~km}^{2}$. By speedy urbanization and high population growth rate, ratio of vehicles has been increased many folds. Presently in 2018, there are more than 1.7 million vehicles in the city with an increase of 3300 vehicles per month. Due to semi-arid climate of the area, there is huge dust prevailing round the year except during rainy season in July to August each year. In addition, a huge burden of vehicles on this metropolitan city is adding worst conditions in relation to air pollution. Motor vehicles and thousands of small and large industries are the main sources of air pollution in this city (Rasheed, 2015). It experiences high usage of personal vehicles. Mass transit system of the city comprised buses and vans, which contribute heavily to air pollution due to poor traffic management system in the city (Qadir, 2002). Several studies have demonstrated, traffic increase by 1.5 times with an average annual growth rate of $3.75 \%$ in Lahore. Of total traffic on Lahore road network, $35 \%$ is shared by passenger cars and jeeps, $30 \%$ by motor cycles, $15 \%$ by non-motorized vehicles and $8 \%$

*Author for correspondence;

E-mail: rehman.kashif@uvas.edu.pk by public transport. An alarming situation of air pollution is being experienced for last many years especially in the evening hours. It becomes very difficult to breathe on road side of Lahore due to huge crowd of private and public transport. This city also experienced smog formation during October and December in 2016 first time in Pakistan's history and same is being experienced in winter season 2017.

Both natural and anthropogenic factors are responsible for land, water and air pollution. The entrance of harmful gases and smoke from vehicles and industries into the atmosphere causes air pollution (Zell et al., 2010). It is globally accepted that vehicular and industrial emission and burning of municipal solid wastes are the main anthropogenic air pollution sources in urban areas. Gases emitted directly from the tailpipe of motor vehicles into the air are said to constitute pollution caused by vehicles. Automobile emission alone is responsible for two third of air pollution towards air quality in urban areas. Carbon monoxide (CO), oxides of sulphur ( $\mathrm{SO}_{\mathrm{x}}$ ), nitrogen oxides $\left(\mathrm{NO}_{\mathrm{x}}\right)$, hydrocarbons $(\mathrm{HC})$ and particulate matter (PM) are the primary air pollutants found in urban areas which are all associated with vehicles as they emit high levels of all of these gases; particularly carbon monoxide and the unburned hydrocarbons (HC), and oxides of nitrogen as well as 
PM, can be damaging for human health and the environment and some are carcinogenic as well. World Health Organization (WHO) has reported that in the year 2016, ambient air pollution was responsible for 4.2 million death worldwide estimated to cause $16 \%$ lungs cancer deaths, $25 \%$ chronic obstructive pulmonary disease (COPD) deaths, $17 \%$ ischemic heart disease and stroke and $26 \%$ respiratory infections deaths (WHO, 2018).

The effect of vehicular emissions can be observed at three levels; at local level in terms of ambient air quality deterioration, noise level and visibility, at regional level in the form of acid rain, and at global level as the global warming issue (Khathuria, 2002). Vehicular exhaust directly affects the respiratory system, increasing mortality and impropering pulmonary function are said to be associated to high level of sulphur (Imtiaz et al., 2008). High level of lead hampers the hemoglobin synthesis in bone marrow (Bhandarkar, 2013). Acute Respiratory Infection (ARI) and asthma are the diseases, children most commonly suffer from; both related to air pollution. Transportation density is increasing day by day globally. Road transport accounts for $22.5 \%$ total global $\mathrm{NO}_{\mathrm{X}}$ and $21.2 \%$ of PM emission (Takeshita, 2011; Jain, 2007). Like other world, the major sources of air pollutants are vehicular exhaust, natural dust, industrial stacks and garbage burning in the Pakistan. It was observed during a study in Pakistan that the pollutants emitted from motor cycles and rickshaws include carbon monoxide (31\%), hydrocarbons 68\% and nitrogen oxides (1\%). The total pollutants emitted from diesel driven mini buses was minimum, while for motor cycles was maximum (Sadiq et al., 2001). In another study conducted in Peshawar, a major city of Pakistan, it was found that pollutants (nitrogen oxides, hydrocarbons, lead and particulate matters) emitted from cars, buses, truck and rickshaw were much higher as compared to National Environment Quality Standards (NEQS) of Pakistan (Khan et al., 2008). According to survey 33\% residents were suffering from asthma in Peshawar city in 2003 (Khwaja and Khan, 2005). Level of $\mathrm{NO}_{\mathrm{x}}, \mathrm{PM}_{10}$ and $\mathrm{CO}$ were recorded in Lahore and their emissions were compared with WHO standards. High concentration of particulate matter, sulphur dioxide, oxides of nitrogen and ozone was recorded in Lahore during mid-1990s, and 2-16 times higher concentration of toxic gases was observed in reference to WHO guidelines in Lahore (Schneid, 2010). Lahore, a metropolitan city of Pakistan is observing low outdoor air quality for many years. Heavy migration of population from rural areas towards this city is also posing threats to air quality of this city. It is dire need of time to evaluate different vehicles in the scenario of quality and number of vehicles, running on roads to avoid future smog formation in this mega city.

\section{Materials and Methods}

This study was conducted in the Department of Environmental Sciences, University of Veterinary and Animal Sciences, in Lahore, Pakistan. Objective of the study was to evaluate different groups of vehicles for their contribution towards ambient air quality and smog formation scenario in the city. The vehicles were categorized into following groups for analysis of vehicular exhaust gases.

Group A : Motor cycles

Group B : Qingqi rickshaw (locally developed motorcycle rickshaw in Pakistan)

Group C : Locally manufactured cars

Group D : Imported re-conditioned cars Group E : Public transport vans.

Each group consisted of 30 vehicles at random on road with same year of manufacturing. Monitoring of vehicles exhaust was done weekly from April to September using LANCOM III flue gas analyzer from LAND Instruments International, USA which was calibrated using standard reference gases provided with the instrument. This instrument can measure $\mathrm{O}_{2}(0-25 \%$ by volume), $\mathrm{CO}(0-2000 \mathrm{ppm}), \mathrm{SO}_{2}(0-2000 \mathrm{ppm})$, Nitric oxide NO (0-1000 ppm), Nitrogen dioxide $\mathrm{NO}_{2}$ (0-100 ppm), Hydrogen sulphide $\mathrm{H}_{2} \mathrm{~S}$ (0-200 ppm) and hydrocarbons $\mathrm{C}_{\mathrm{x}} \mathrm{H}_{\mathrm{y}}$ ( $0-5 \%$ by volume). For this study three high-traffic areas (Outfall road, Lower Mall road and Mall road) were selected being nearest high traffic area. Vehicular exhaust was measured for different pollutants ( $\mathrm{CO}, \mathrm{SO}_{2}, \mathrm{NO}_{2}, \mathrm{NO}, \mathrm{NOx}, \mathrm{H}_{2} \mathrm{~S}$ and $\left.\mathrm{HC}\right)$. The instrument being portable was used to measure pollutants from vehicular exhaust by inserting probe into vehicular exhaust pipe and after stability time of $3 \mathrm{~min}$, reading was recorded. Gas flow rate of $1.2 \mathrm{~L} / \mathrm{min}$ was used for measurements. A second reading was taken at $6 \mathrm{~min}$ and average of both readings was used. Data of 30 vehicles in a group was pooled and average value was used. Data was recorded in ppm or $\mathrm{g} / \mathrm{km}$. It was converted to $\mathrm{mg} / \mathrm{m}^{3}$ where necessary due to available standard in these units using following formula (Champan, 2007):

$$
\mathrm{mg} /=\frac{\mathrm{ppm} \times \text { molecular weight }}{22.4}
$$


All measurements were replicated three times. Ambient concentration of pollutant gases were also monitored using Haz scanner HIM-6000 from Environmental Devices Corporation, USA for monitoring ambient air quality for different pollutants i.e. $\mathrm{CO}, \mathrm{NO}, \mathrm{NO}_{2}, \mathrm{NO}_{\mathrm{x}}$, $\mathrm{O}_{3}, \mathrm{H}_{2} \mathrm{~S}, \mathrm{SO}_{2}$, VOCs, $\mathrm{PM}_{2.5}$ and $\mathrm{PM}_{10}$ during onset of smog formation in the months of October and November, 2017.

\section{Results and Discussion}

Metropolitan Lahore with a total area of $1,772 \mathrm{~km}^{2}$ and a population of 11.13 million heads in 2017 has rising air pollution issue due to huge traffic on roads. The year 2016 was the first year in the history of Lahore with smog formation. Smog formation was also observed in the year 2017 and it is expected that if vehicular and industrial exhausts are not monitored for the exhaust, situation may become verse and it may become very difficult to overcome air pollution and smog issue in this city. To evaluate contribution of vehicles towards prevailing air pollution five major air pollutants from vehicular exhaust viz. carbon mono oxide (CO), Nitrogen dioxide $\left(\mathrm{NO}_{2}\right)$, Sulphur dioxide $\left(\mathrm{SO}_{2}\right)$, Hydrogen Sulphide $\left(\mathrm{H}_{2} \mathrm{~S}\right)$, Nitric oxide (NO) and Hydrocarbons (HC) were monitored using LANCOM III flue gas analyzer. The results are summarized as under.

Concentration of carbon monoxide (CO). Carbon monoxide is a pollutant which comes from engine exhaust mainly as anthropogenic activity and contributes about $60 \%$ to global CO emission. It is mainly absorbed through respiratory system (lungs), bonds with hemoglobin and forms carboxyhemoglobin which reduces oxygen level in blood. Carbon monoxide may cause drowsiness, unconsciousness or even death. Global $\mathrm{CO}_{2}$ emissions from human activities (fossil fuels, industry and others) have been reported around 41 billion tonnes carbon dioxide in 2017 whereas from fossil fuels and industry alone are estimated around 37 billion tonnes. As estimated through previous studies in Lahore, about $92 \%$ of $\mathrm{CO}$ is shared to total $\mathrm{CO}$ production in the city. Carbon monoxide emissions from different groups of vehicles are presented in Fig. 1. The results indicated that maximum concentration of CO was observed in Qingqi rickshaw $(4.89 \mathrm{~g} / \mathrm{km})$ followed by public vans $(4.18 \mathrm{~g} / \mathrm{km})$. Lowest concentration was observed in motorbikes $(2.93 \mathrm{~g} / \mathrm{km})$. Cars, either local or imported reconditioned, have bit higher conc. of $\mathrm{CO}(3.11 \mathrm{~g} / \mathrm{km}$ and $3.05 \mathrm{~g} / \mathrm{km})$ than
NEQS and European Standard (Table 1) which limits $\mathrm{CO}$ emission for passenger vehicles to $2.72 \mathrm{~g} / \mathrm{km}$. High $\mathrm{CO}$ emission indicates a fuel mixture richer than ideal. Carbon monoxide (CO) is an indicator of engine fuel combustion efficiency. Presence of carbon monoxide (CO) in exhaust is directly indicating air fuel mixing ratio which might be due to inadequate $\mathrm{O}_{2}$ supply needed for efficient combustion. This might be due to lack of proper maintenance of vehicles or due to overloading of passengers in transport vehicles. According to studies, the lower level of $\mathrm{NO}_{\mathrm{x}}$ (mainly $\mathrm{NO}$ and a smaller proportion of $\mathrm{NO}_{2}$ ) in vehicular emissions are caused by rich fuel/air stoichiometric conditions mainly due to a lack of excess oxygen, whereas carbon monoxide (CO) emission peak is solely caused by a lack of adequate air for complete combustion in gasoline engines (Mahmoudi et al., 2017).

Concentration of sulphur dioxide $\left(\mathrm{SO}_{2}\right)$. The results of $\mathrm{SO}_{2}$ emissions from different groups of vehicles are presented in Fig. 2. In ambient air $\mathrm{SO}_{2}$ should not exceed $80 \mathrm{ug} / \mathrm{m}^{3}$ but its standard value in vehicular exhaust is

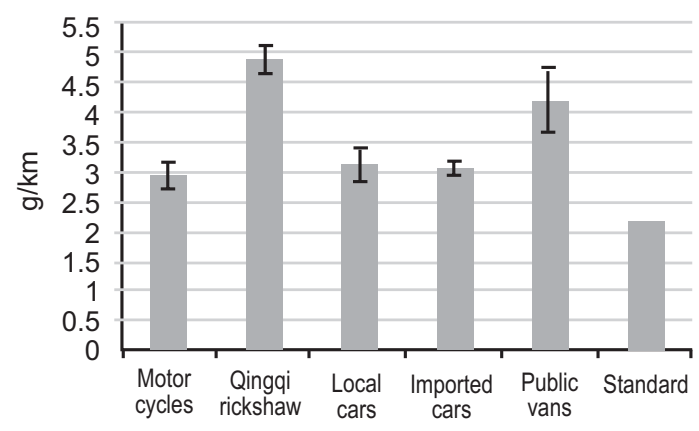

Fig. 1. Average concentration of $\mathrm{CO}$ in different groups of vehicles

Table 1. Vehicular exhaust standard values (NEQs for Pakistan and European standards)

\begin{tabular}{|c|c|c|}
\hline Criteria Pollutant & Limit & Reference \\
\hline \multirow[t]{4}{*}{ Carbon monoxide (CO) } & $2.20 \mathrm{~g} / \mathrm{km}$ & Pakistan Environnent \\
\hline & & Quality Standards, 2016. \\
\hline & $1.0 \mathrm{~g} / \mathrm{km}$ & For new vehicles \\
\hline & $2.72 \mathrm{~g} / \mathrm{km}$ & European standard. \\
\hline \multirow[t]{2}{*}{$\mathrm{HC}+\mathrm{NOx}$} & $0.7 \mathrm{~g} / \mathrm{km}$ & Pakistan Environnent \\
\hline & & Quality Standards, 2016. \\
\hline Oxides of nitrogen $\left(\mathrm{NO}_{\mathrm{X}}\right)$ & $0.5 \mathrm{~g} / \mathrm{km}$ & European standard. \\
\hline Total hydrocarbons (THC) & $0.2 \mathrm{~g} / \mathrm{km}$ & European standard. \\
\hline
\end{tabular}


not available as most of the countries have monitoring on presence of sulphur in fuels. At present in Pakistan, there is no strict compliance of standards in gasoline so there was $\mathrm{SO}_{2}$ recorded in vehicular exhausts. Maximum emission was recorded in Qingqi rickshaw group $\left(715 \mathrm{ug} / \mathrm{m}^{3}\right)$ followed by local cars $\left(435 \mathrm{ug} / \mathrm{m}^{3}\right)$. The lowest $\mathrm{SO}_{2}$ concentration was observed in imported cars $\left(125 \mathrm{ug} / \mathrm{m}^{3}\right)$. Qingqi rickshaw group was most of the time over loaded with 7-8 passengers whereas in local cars absence of catalytic converters might be possible reason of high amount of $\mathrm{SO}_{2}$ in vehicular exhaust or there might be high amount of sulphur present in fuels which after combustion produce high levels of $\mathrm{SO}_{2}$.

Concentration of nitrogen oxides $\left(\mathrm{NO}_{2} \& \mathrm{NO}\right)$. The results presented in Fig. 3 indicated that almost all groups of vehicles are emitting $\mathrm{NO}_{\mathrm{x}}$ higher than NEQS and European standards (Table 1). According to the standard, $\mathrm{NO}_{\mathrm{x}}$ should not exceed $0.5 \mathrm{~g} / \mathrm{km}$. $\mathrm{NO}_{\mathrm{x}}$ found

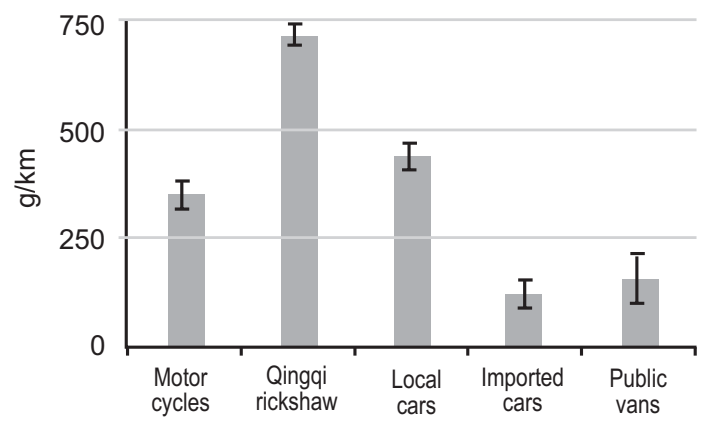

Fig. 2. Average concentration of $\mathrm{SO}_{2}$ in different groups of vehicles

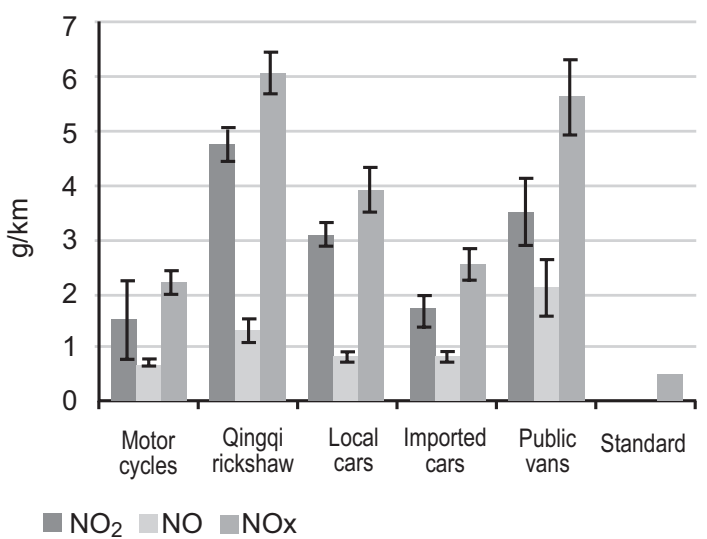

Fig. 3. Average concentration of $\mathrm{NO}_{2}, \mathrm{NO}$ and $\mathrm{NO}_{\mathrm{x}}$ in different groups of vehicles in exhaust of Qingqi rickshaw $(6.04 \mathrm{~g} / \mathrm{km})$ were almost 12 times higher than standard value. This group was followed by public vans where 10 times higher value $(5.6 \mathrm{~g} / \mathrm{km})$ was recorded. Lowest concentration of $\mathrm{NO}_{\mathrm{x}}$ was recorded in motorcycle group $(2.2 \mathrm{~g} / \mathrm{km})$. Overall, $\mathrm{NO}_{\mathrm{x}}$ emissions in all groups of vehicles were 4-12 times higher than the standards.

Oxides of nitrogen $\left(\mathrm{NO}_{\mathrm{x}}\right)$, are normally formed when combustion temperatures rises from $2500^{\circ} \mathrm{F}$ in such a condition that there is high load on engine. Due to these excessive temperature conditions during combustion, the release of $\mathrm{NO}_{\mathrm{x}}$ is highly increased at a stoichiometric point because the engine at those conditions is under a light load. When the engine during combustion process is burning fuel at or near stoichiometric point, $\mathrm{NO}_{\mathrm{x}}$ levels release on acceleration of engine will be typically higher than measured at cruise conditions or during deceleration of the speed. Ideally, the $\mathrm{NO}_{\mathrm{x}}$ values at idle conditions will be 0 ppm typically. At ambient concentrations, nitric oxide (NO) is not considered to be hazardous to health, but nitrogen dioxide $\left(\mathrm{NO}_{2}\right)$ can

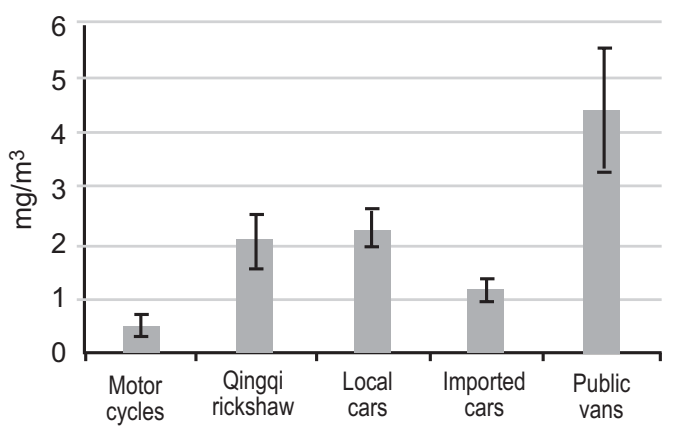

Fig. 4. Average concentration of $\mathrm{H}_{2} \mathrm{~S}$ in different groups of vehicle

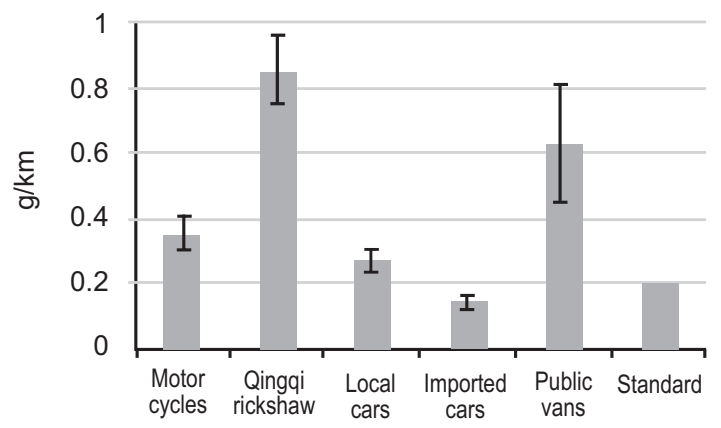

Fig. 5. Average concentration of $\mathrm{HC}$ in different groups of vehicles. 

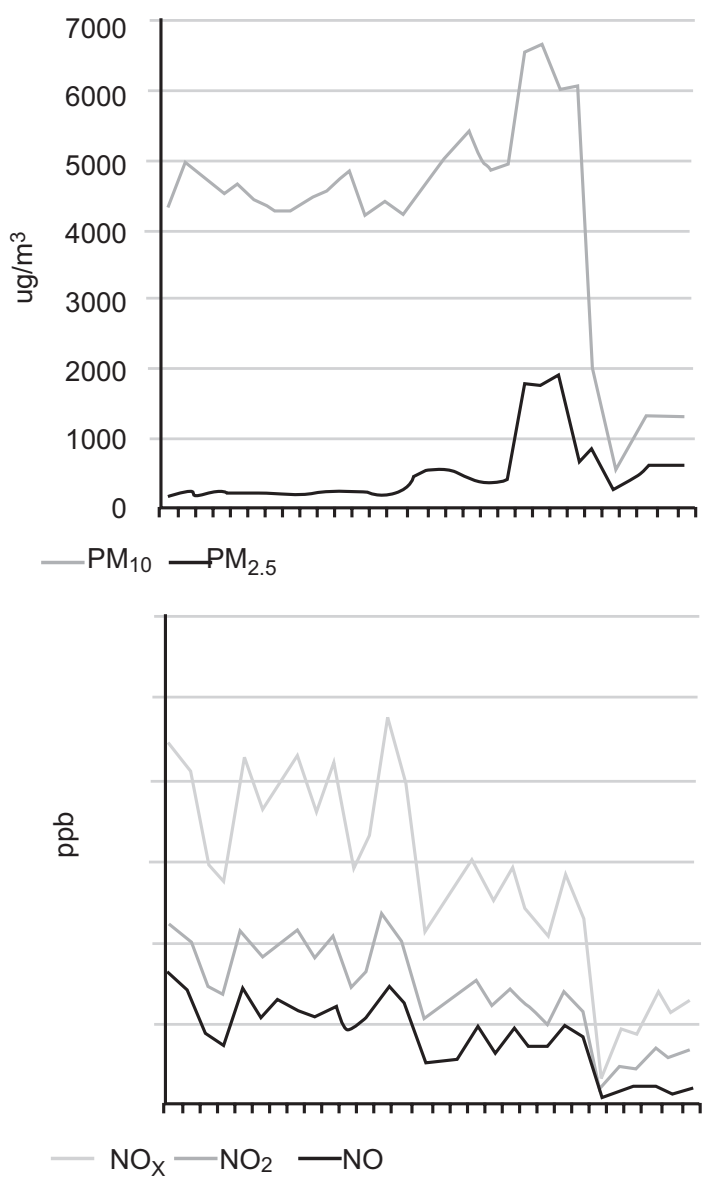
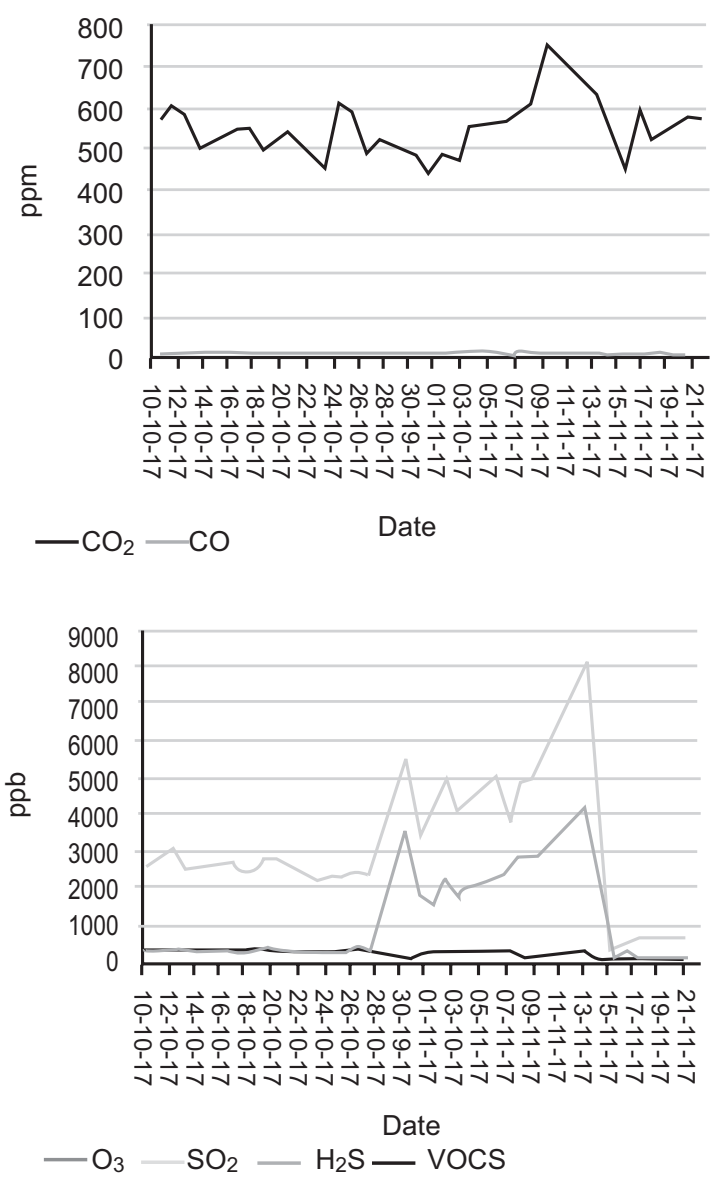

Fig. 6. Ambient concentration of different pollutants in Lahore during October \& November, 2017.

be dangerous for health. $\mathrm{NO}_{\mathrm{x}}$ gases which can easily react in the presence of solar UV to form smog and acid rain as well as being central to the formation of fine particles (PM) and ground level ozone, both of which are associated with adverse health effects.

Concentration of hydrogen sulphide $\left(\mathrm{H}_{2} \mathrm{~S}\right)$. The results for $\mathrm{H}_{2} \mathrm{~S}$ in vehicular exhaust are presented in Fig. 4. European Standards are not available for this gas in vehicular exhaust. The results indicated that highest concentration of $\mathrm{H}_{2} \mathrm{~S}$ was observed in public vans (4.43 $\mathrm{mg} / \mathrm{m}^{3}$ ) which were followed by local cars and Qingqi rickshaw $\left(2.3 \mathrm{mg} / \mathrm{m}^{3}\right.$ and $2.07 \mathrm{mg} / \mathrm{m}^{3}$, respectively). Lowest concentration was observed in motorcycles and imported vehicles.

Hydrogen sulphide $\left(\mathrm{H}_{2} \mathrm{~S}\right)$ is a colourless but flammable, highly toxic gas. The major route of hydrogen sulphide exposure is inhalation. This gas is readily absorbed through lungs. The odor threshold $(0.5 \mathrm{ppb})$ for this gas is much lower than the OSHA ceiling (20 ppm).
However, although strong odor is readily identified, olfactory fatigue in humans may occur at high concentrations and at continuous low concentration exposures. Due to this reason, odor is not considered as a reliable indicator of $\mathrm{H}_{2} \mathrm{~S}$ presence and may not provide adequate warning of hazardous concentrations in advance. As hydrogen sulphide $\left(\mathrm{H}_{2} \mathrm{~S}\right)$ is slightly heavier than air, it may accumulate in poorly ventilated, low lying enclosed areas causing death of humans.

Concentration of hydrocarbons (HC). The results for HCs measured for different groups are presented in Fig. 5. The results indicated that highest $\mathrm{HC}$ emission was observed in Qingqi rickshaw $(0.85 \mathrm{~g} / \mathrm{km})$ which was almost 4 times higher than European standards (Table 1) $(0.2 \mathrm{~g} / \mathrm{km})$. It was followed by public vans $(0.63 \mathrm{~g} / \mathrm{km})$. However, imported vehicles have HC emissions $(0.15 \mathrm{~g} / \mathrm{km})$ which is much below standards value of $0.2 \mathrm{~g} / \mathrm{km}$. Local cars and motor cycles have a little bit higher value for $\mathrm{HC}$ emissions as compared to standard value. 
Emission controlled vehicles have normally below 100 ppm of $\mathrm{HC}$ in exhaust whereas non emission controlled vehicles have relatively higher concentration of $\mathrm{HC}$ in emission (400 ppm). There are number of factors which contribute increased $\mathrm{HC}$ emissions during vehicular combustion like defective ignition components, improper ignition timing, defective catalytic converter, defective air injection components, lean fuel mixture and low cylinder compression. High hydrocarbon (HC) readings in vehicular emissions usually indicate excessive unburned fuel present in exhaust.

Smog forming capacity of automobile exhaust. Smog is not simply smoke and fog but it has different pollutants and compounds of nitrogen which react in the presence of solar UV to form secondary pollutants in lower atmosphere in winter. This smog may be irritant to eyes and also have other adverse effects on respiratory systems in humans and animals during winter season. Vehicular exhaust especially nitrogen compounds are a proven source of smog formation when combined with specific meteorological conditions in metropolitans where huge number of vehicles are on roads with very slow speed moving due to rush and producing high amount of pollutants with a great chance of smog formation in cool weather conditions. Millions of automobiles are responsible for the ozone containing eye irritating and vegetation damaging smog to the area. Smog formation resulted with atmospheric reactions of nitrogen compounds and olefinic compounds reactions in lower atmosphere under cool climatic conditions in winter. During a study, it was found that unburnt fuel in gasoline powered engine exhaust is much higher during idle conditions as well as during deceleration as compared to acceleration and cruising. Similarly NO is also much higher in vehicular exhaust on idle and deceleration conditions than at acceleration and cruising. Traffic congestion especially in rush hours increases vehicle emissions and degrades ambient air quality in metropolitan cities, and recent studies have shown excess morbidity and mortality for drivers, commuters and individuals living near major roadways (Zhong and Batterman, 2014).

Ambient concentration of pollutant gases during smog formation in local atmosphere. Concentration of different gases in ambient air is presented in Fig. 6. Results indicated that high amount of $\mathrm{PM}_{2.5}, \mathrm{PM}_{10}$; Sulphur dioxide concentrations in addition to higher $\mathrm{NO}_{\mathrm{x}}$ were present in atmosphere in ambient air. Concentration of $\mathrm{CO}_{2}$ was also very high in the ambient air (600-750 ppm). $\mathrm{PM}_{2.5}$ and $\mathrm{PM}_{10}, \mathrm{NO}, \mathrm{NO}_{2}\left(\mathrm{NO}_{\mathrm{x}}\right)$ concentration was decreased whereas concentration of $\mathrm{O}_{3}, \mathrm{H}_{2} \mathrm{~S}$ and VOCs were increased in November than October. Concentration of $\mathrm{CO}$ in both months almost remains the same.

\section{Conclusion}

It is concluded from this study that all types of vehicles emit gaseous pollutants much higher than NEQS/ European Standard. Public transport vehicles (Qingqi rickshaw and vans) contribute more towards atmospheric pollution in the city. Both locally manufactured and imported cars are comparatively cleaner. It is therefore need of the time to control air pollution as contributed by different groups of vehicles to keep exhaust gases as under NEQS for healthy life by avoiding smog formation in this metropolitan city. It is also need of the time to reduce vehicular emissions by maintaining proper maintenance of the engine, by putting a ban on high pollution releasing vehicles like Qingqi rickshaw, by controlling overloading on public transport and by expansion of roads to reduce traffic congestion especially in peak rush hours. If the government ignores the vehicular exhaust gases which are being emitted beyond NEQS, due to high $\mathrm{PM}_{2.5} \& \mathrm{PM}_{10}, \mathrm{NO}_{\mathrm{x}}, \mathrm{H}_{2} \mathrm{~S}, \mathrm{SO}_{\mathrm{x}}$ and VOCs in air, smog formation may not stop in coming years in this metropolitan city.

Conflict of Interest. The authors declare no conflict of interest

\section{References}

Champan, L. 2007. Transport and climate change: A review. Journal of Transport Geography, 15: 354-367.

Imtiaz, N. , Aftab, T., Tariq, M., Shafiq, T. 2008. NOx emission from light weight vehicles. Journal of Chemical Society of Pakistan, 30: 683-687.

Jain, A.K., Hayhoe , K.S.A. 2007. Global air pollution problems In: Hand book of Atmospheric Sciences and Application, vol 2, pp. 623-633, Blackwell Science Ltd, Malden, USA.

Khan, M., Khan, A.R. , Aslam, M.T., Anwar, T., Shah, J. 2008. Study of atmospheric pollution due to vehicular exhaust at the busy cross roads in Peshawar city Pakistan and its minimizing measures. Journal of Chemical Society of Pakistan, 30: 1619. 
Khathuria, V. 2002. Vehicular pollution control- Concept note. Transportation Research, Part D. 7: 373-378.

Khwaja, M.A., Khan, S.R. 2005. Air Pollution: Key Environmental Issues in Pakistan. Sustainable Development Policy Institute, Islamabad, Working Paper \# 99

Mahmoudi, A.R., Khazaee, I., Ghazikhani, M. 2017. Simulating the effects of turbocharging on the emission levels of a gasoline engine. Alexandria Engineering Journal, 56: 737-748.

Qadir, F.N. 2002. Air Quality Management in Pakistani Cities: Trends and Challenges. Better Air Quality in Asian and Pacific Rim Cities. 16-18 Dec, 2002, Hong Kong Convention and Exhibition Centre, Hong Kong.

Rasheed, A., Aneja, V.P., Aiyyar, A., Rafique, V. 2015. Measurement and analyses of fine particulate matter (PPM2, 5) in urban areas of Pakistan. Aerosol and Air Quality Research, 15: 426-439.
Sadiq, H., Khan, S.U., Khalil, K. 2001. Prevalence of motor vehicle emission at selected places of Faisalabad city. Pakistan Journal of Agricultural Sciences, 38: 54-55.

Schneidemesser, E.V., Stone, E.A., Quraishi, T.A., Shafer, M.M., Schauer, J.J. 2010. Toxic metals in the atmosphere in Lahore, Pakistan. Science of Total Environment, 408:1640-1648.

Takeshita, T. 2011. Global scenarios of air pollutants emission from road transport through to 2050. International Journal of Environmental Research and Public Health, 8: 3032-3062.

WHO, 2018. Mortality and burden of disease from ambient air pollution. World Health Organization. http://www.who.int/gho/phe/outdoor_air_polluti on/burden_text/en/assesses on 04-07-2018

Zhang, K., Batterman, S. 2014. Air pollution and health risks due to vehicle traffic. Science of Total Environment, 15: 307-316. 